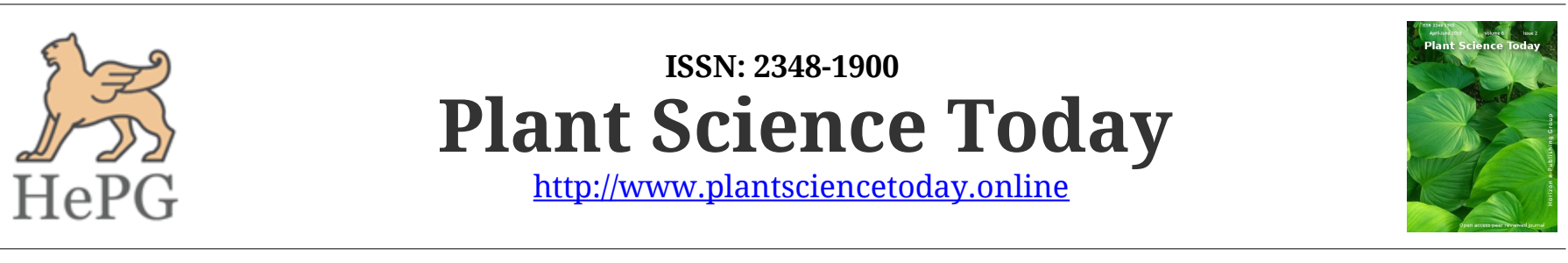

OPEN ACCESS

Research Article

\title{
Conservation of Garcinia imberti Bourd. through seeds
}

\author{
Anto M, Angala M, Jothish P S \& Anilkumar C ${ }^{*}$ \\ Conservation Biology Division, Jawaharlal Nehru Tropical Botanic Garden and Research Institute, Palode, Thiruvananthapuram 695562 , \\ Kerala, India
}

\section{Article history}

Received: 02 March 2019

Accepted: 28 April 2019

Published: 31 May 2019

\section{Publisher}

Horizon e-Publishing Group

\section{*Correspondence}

Anilkumar C

至anildeepa@yahoo.co.in

\begin{abstract}
Garcinia imberti seeds were collected during 2015-2017 from Shangili, Cheenikkala and Bonaccord evergreen forests of Agasthyamala Biosphere Reserve, the only abode of this endangered endemic species. Germinability of seeds were analysed through decoating, Gibberellic acid $\left(\mathrm{GA}_{3}\right)$ and light inductive pre-treatments on fresh (62.8 \% moisture content; MC) and desiccated (fast; $23.3 \% \mathrm{MC}$ and slow; $30.5 \% \mathrm{MC}$ ) seeds. The seed germination with impermeable coat $(0.7-1.2 \mathrm{~mm})$ was restricted which on decoating got enhanced. Application of $\mathrm{GA}_{3}$ along with exposure to light breaked dormancy within 4-6 days compared to non-treated seeds that took 238-254 days to germinate. Stored seeds behaviour revealed that seed moisture content and rate of germination were negatively correlated. Seed storage was found to be more efficient only up to 80 days at controlled seed banking conditions $\left(20 \pm 2{ }^{\circ} \mathrm{C}, 20 \%\right.$ relative humidity; RH). Both fast and slow desiccated seeds stored for 60 days in seed bank conditions exhibited 50.4 and $43.4 \%$ of germination compared $39.4 \%$ germination of non-desiccated seeds. Hence fast desiccated and decoated $G$. imberti seeds pre-treated with $\mathrm{GA}_{3}$ on subsequent exposure to light alleviated dormancy. For seed banking, fast desiccated seeds with MC in between $40-20 \%$ are found to be promising.
\end{abstract}

Keywords: Agasthyamala Biosphere Reserve; Desiccation; Dormancy, Endangered; Seed storage practices.

Citation: Anto M, Angala M, Jothish PS, Anilkumar C. Conservation of Garcinia imberti Bourd. through seeds. Plant Science Today 2019;6(2):243-251. https://doi.org/10.14719/pst.2019.6.2.518

Copyright: (C) Anto et al (2019). This is an open-access article distributed under the terms of the Creative Commons Attribution License, which permits unrestricted use, distribution, and reproduction in any medium, provided the original author and source are credited (https://creativecommons.org/licenses/by/4.0/).

Indexing: Plant Science Today is covered by Scopus, Web of Science, BIOSIS Previews, ESCI, CAS, AGRIS, CABI, Google Scholar, etc. Full list at http://www.plantsciencetoday.online

\section{Introduction}

Seed germination is a complex physiological process that responds to environmental signs such as light, temperature, water potential etc. Seed germination failure and dormancy is the main limiting factor of threatened plants for large scale production. Bewley and Black (1) reported that certain seeds require treatment both for eliminating hard resistant seed coat and endogenous dormancy. Exogenous dormancy imposed seeds have rigid pericarp/seed coat that are impermeable to water and oxygen. The seed coat or testa of many plants comprises significant amount of germination inhibitor, which prevent seed germination (2). Nearly 95\% dormancy of seeds are physiological or biochemical in nature, while for the rest of dormant seeds enforced dormancy is due to an impermeable seed coat (3). The seed coat inhibitory effects on seed germination are caused by some possible process such as mechanical constraint, prevention of water and oxygen uptake and production of chemical inhibitors (4). Certain process like hot or cold water scarification, chemical 
scarification, seed decoating, etc. are sufficient to overcome this coat imposed on dormancy. The endogenous dormancy imposed seeds are in need of after-ripening, either high or low temperature and moisture, or both in sequence to break dormancy. Seed dormancy may be able to overcome by using a number of processes which stimulate germination by physical or physiological treatments. $\mathrm{GA}_{3}$ is used as a stimulator to enhance seed germination credited by the mobilization of stored food reserves (5). This case is akin to the effect of light in using the nutrients for photosynthesis (6).

Garcinia imberti is an evergreen, endangered tree species (7) growing up to $10 \mathrm{~m}$ height bearing recalcitrant seeds with high moisture content. The niche specificity is due to its patchy, specific altitudinal $(600-1200 \mathrm{~m}$ asl) distribution, recruitment failure due to high fruit/seed predation and a prolonged period of seed dormancy (8). The major difficulty in G. imberti propagation as for many species of Garcinia genus is related to its seeds germination, dormancy and storage aspects. Because of seed dormancy, G. imberti seeds can take 14 months in its niche to germinate due to the physical barrier of the seed coat $(9,8)$. Niche based cues on the ecological requirements preferred by $G$. imberti seedlings indicated the presence of balancing nature of sunlight and misty shaded canopy. Natural occurrence of more $G$. imberti seedlings at the forest floor where canopy gaps formed by uprooted trees or shrubs indicated the azimuthal proactive effect on seed germination. Germination performance induced by light are likely to fluctuate among habitats, for example in shaded areas, the occurrence of strong light can be associated with a canopy gap that enhance chances for developing seedlings (10). These observations validated confirmatory experiments on the light enhanced $G$. imberti seed germinability.

The importance of seed storage in plants especially endangered as well as plants at the brink of extinction has been practised ever since humans initiated to domesticate plant species. However, the successful seed storage depends on knowledge concerning the seed's behaviour during storage, which allows the use of applicable environments that maintain their sustainability (11). Ex-situ seed conservation is 100 times economic than the in-situ protection of individual trees (12). Storage possibilities of tree seeds are vastly species-specific and huge variation has been faced across the tree species (13). The seed storage life-span of G. imberti is very limited as other species of Garcinia due to its recalcitrant nature and elevated moisture contents. The aim of the study was to find out suitable solutions to overcome seed dormancy and to extend seed storage of $G$. imberti.

\section{Materials and Methods}

G. imberti fruits were collected during 2015-2017 November with 25 accessions each from Shangili (1185 m, N 0847’48.90”, E 077¹1'45.44”), Cheenikkala (1124m, N $\left.8^{\circ} 47^{\prime} 46^{\prime \prime}, \mathrm{E} 77^{\circ} 9^{\prime} 2 "\right)$ and Bonaccord (643 m, N 845’25”, E 77¹1'20”) evergreen forests of Agasthyamala Biosphere Reserve. Mature ripened fruits were recognized by their yellowish-green colour and these fruits were directly harvested from the mother trees. After collecting, the fruits were brought to the laboratory and the rinds removed by manual pressing. These seeds were thoroughly washed with running water and thereafter allowed to surface dry in laboratory conditions.

The following aspects were analysed in order to evaluate

\section{(1) Overcome seed dormancy}

1. Coated seeds + dark (control)

2. Coated seeds + light

3. Coated seeds + light $+\mathrm{GA}_{3}$ (regular intervals of 0-5000 ppm concentration)

4. Decoated seeds + dark

5. Decoated seeds + light

6. Decoated seeds + light $+\mathrm{GA}_{3}$ (regular intervals of 0-5000 ppm concentration)

Impermeable seed coat $(0.7-1.2 \mathrm{~mm})$ of $G$. imberti seeds restricts the germination to a certain extent. Even though various methods like seed decoating, light and $\mathrm{GA}_{3}$ treatments were applied to reduce the dormancy and enhance/induce the percentage germination. For that purpose, the hard outer and thin inner seed coat was removed mechanically. For $\mathrm{GA}_{3}$ treatments, seeds were pre-treated with $\mathrm{GA}_{3}$ solutions of different concentrations $(0,50,250$, $500,1000,2000,3000,4000$ and $5000 \mathrm{ppm}$ ) for both coated and decoated seeds. Seeds submerged in distilled water for 24 hours were considered as control. The all tested seeds (12 seeds/ 10 lots) were placed over filter paper wetted with distilled water in light transparent petri dishes, kept in seed germinator $\left(30 \pm 2^{\circ} \mathrm{C}, 80 \% \mathrm{RH}\right)$ with light (provided by Philips daylight lamps (15.4 Lux)) and without light.

\section{(2) Seed storage aspects}

Seed were kept in six different storage temperature units for analysing the optimum storage conditions for long term seed conservation aspects. The seeds were stored in closed polycarbonate bottles; half portions of the bottles were kept empty to enhance seed respiration. Additional experiments were conducted to assess the viability of both fast and slow desiccated stored seeds for long term storage or conservation programmes. For the storage aspects (7) two different moisture contents above the limit of 


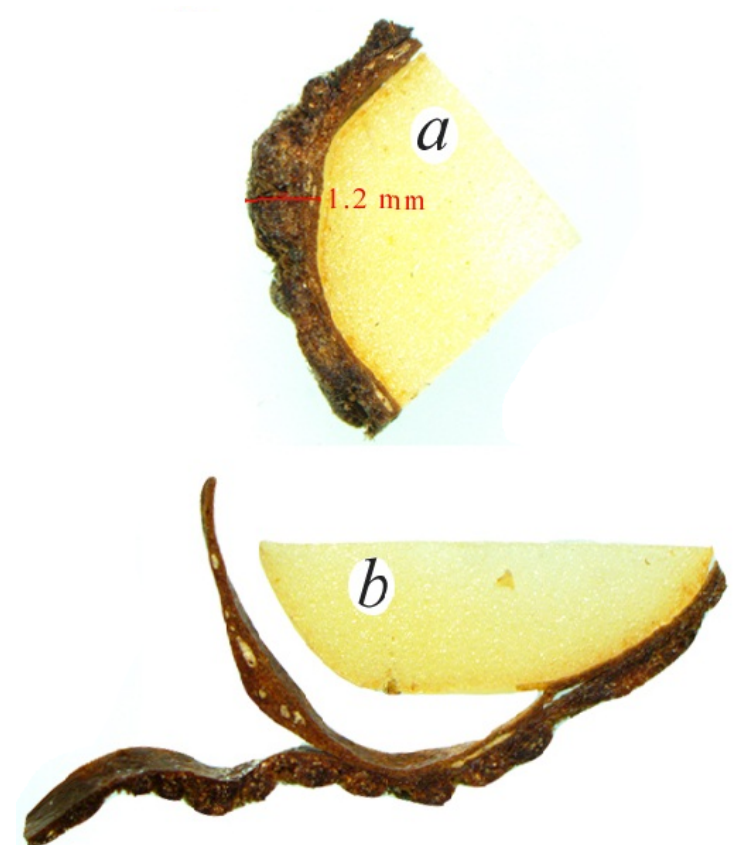

Fig. 1. Seeds with 0.7-1.2 mm thickened seed coat (a. seed section with hard seed coat; $\boldsymbol{b}$. showed its double layer

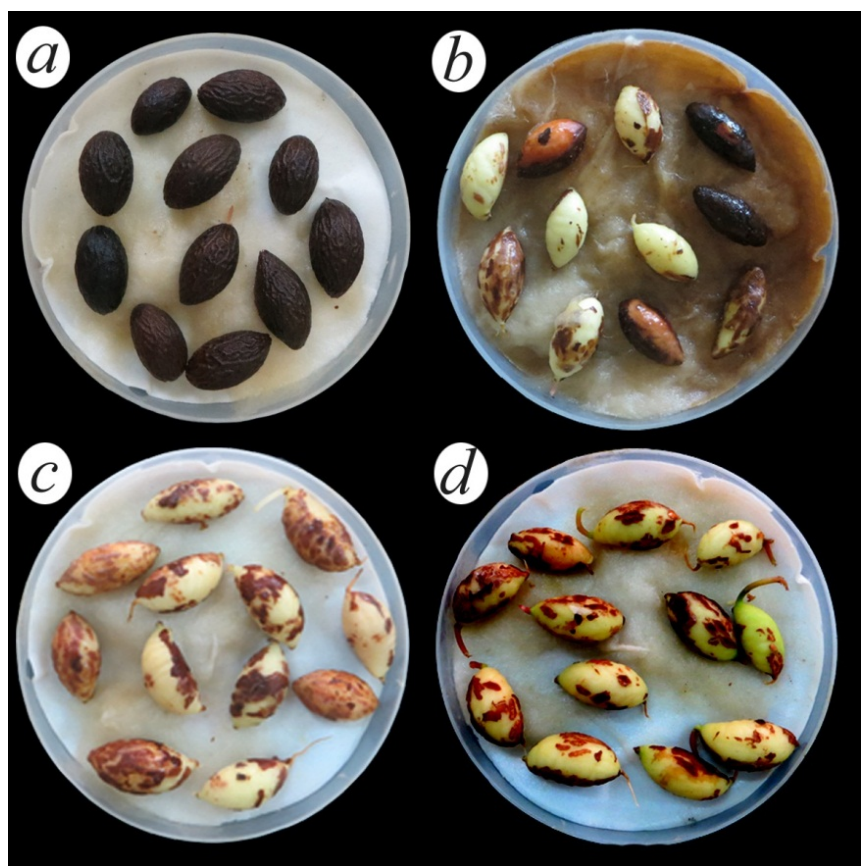

Fig. 2. Different seed dormancy breaking experiments (a. coated seeds+ light $+\mathrm{GA}_{3} 1000 \mathrm{ppm}, \boldsymbol{b}$. decoated seeds + dark, c. decoated seeds + light, $\boldsymbol{d}$. decoated seeds + light $+\mathrm{GA}_{3} 1000$ ppm) critical moisture contents (CMCs), $23.3 \%$ (fast desiccated seed) and $30.5 \%$ (slow desiccated seeds) both registered above $50 \quad \%$ seed germination were considered for storage experiment. For cryopreservation, both desiccated and fresh seeds were covered with aluminium foils before directly dipped to liquid nitrogen for one week; and subsequently defrosted for 5 minutes in water bath $\left(40^{\circ} \mathrm{C}\right)$.

The following storage conditions were used:

1. Seeds stored at laboratory conditions ( $28 \pm$ $\left.2^{\circ} \mathrm{C}, 60 \% \mathrm{RH}\right)$

2. Seeds stored at controlled seed banking conditions $\left(20 \pm 2{ }^{\circ} \mathrm{C}, 20 \% \mathrm{RH}\right)$

3. Seeds stored at $10^{\circ} \mathrm{C}$

4. Seeds stored at $0^{\circ} \mathrm{C}$

5. Seeds stored at $-20^{\circ} \mathrm{C}$

6. Cryopreservation $\left(-196^{\circ} \mathrm{C}\right)$

\section{Seed germination}

Seeds were taken at regular intervals (10 days) for MC analysis and germination tests with ten replicates of 10 seeds/lot rolled in an acid free moist germination paper kept in a seed germinator without light $\left(30 \pm 2^{\circ} \mathrm{C}, 80 \% \mathrm{RH}\right)$. The viability was tested on daily basis on the percentage of germinated seed when the radicle reaches $5 \mathrm{~mm}$. Germination parameters like speed of germination (SPG), mean germination time (MGT) (14), mean daily germination (MDG), peak value (PV) and germination value (GV) (15) were calculated.

\section{Results}

G. imberti seeds are the sole medium of propagation with $62.8 \pm 4.7 \%$ initial moisture content. The 0.7-1.2 mm thick seeds coat (Figure $1 a$ and $b$ ) enforces deep dormancy for 12-14 months with only $38 \pm 1.3 \%$ of germination in in-situ and 6-8 months in controlled germinator conditions (30 $\pm 2{ }^{\circ} \mathrm{C}, 80 \% \mathrm{RH}$, without light) with $12.6 \%$ of germination ex-situ. The seed coat is impermeable to water and gases to certain extent and decoated seeds are devoid of physical dormancy along with enhanced germination.

The present experiments related to different dormancy breaking methods revealed that both coated and decoated seeds on pretreatment with $\mathrm{GA}_{3}$ exhibited significant variation in germination and associated parameters viz. days taken for germination, speed of germination, germination value. The seeds with higher concentration of $\mathrm{GA}_{3}(1000-4000 \mathrm{ppm})$ registered cent percentage of germination along with good rate of germination value. Seed decoating enhances germination, however decoated seeds with $\mathrm{GA}_{3}$ registered higher rate and speedy germination (Table 1). The overall results showed that decoated seeds in the presence of $\mathrm{GA}_{3}$ especially $1000 \mathrm{ppm}$ displayed a good and speedy germination and enhanced germination value. This treatment combination took only 09-12 days for its complete germination compared to 238-254 days by the delayed germination over non-treated coated seeds (Table 1).

The results of different dormancy breaking methods (Fig. 2) indicated that light and $\mathrm{GA}_{3}$ are the main factor that breaks the physiological dormancy. Decoated seeds contacted with light (15.4 Lux) and $\mathrm{GA}_{3}(1000 \mathrm{ppm})$ showed a promising value of cent percentage germination along with speedy germination (1.63), peak value (0.75) and 
Table 1. Effect of $\mathrm{GA}_{3}$ in both coated and decoated seeds without light (in germinator) (G. imberti seeds; $n=25$ ).

\begin{tabular}{|c|c|c|c|c|}
\hline $\begin{array}{c}\text { Treatments (Germinator, } 30 \pm 2^{\circ} \mathrm{C} \text {, } \\
80 \% \mathrm{RH} \text {, without light) }\end{array}$ & $\begin{array}{l}\text { Days taken for initiation to } \\
\text { completion of germination }\end{array}$ & $\begin{array}{l}\text { Germination } \\
\text { Percentage }\end{array}$ & $\begin{array}{c}\text { Speed of } \\
\text { Germination }\end{array}$ & $\begin{array}{l}\text { Germination } \\
\text { Value }\end{array}$ \\
\hline Coated seeds +0 ppm GA (Control) $_{3}$ & $238-254$ & $12.6 \pm 0.4^{\mathrm{a}}$ & $0.0028 \pm 0.0^{\mathrm{a}}$ & $0.0006 \pm 0.0^{\mathrm{a}}$ \\
\hline Coated seeds +50 ppm $\mathrm{GA}_{3}$ & $218-232$ & $13.2 \pm 0.8^{\mathrm{a}}$ & $0.0042 \pm 0.0^{\mathrm{ab}}$ & $0.0002 \pm 0.0^{\mathrm{a}}$ \\
\hline Coated seeds $+100 \mathrm{ppm} \mathrm{GA}$ & $214-221$ & $14.4 \pm 1.2^{\mathrm{a}}$ & $0.0071 \pm 0.0^{\mathrm{b}^{* *}}$ & $0.0019 \pm 0.0^{\mathrm{a}}$ \\
\hline Coated seeds $+250 \mathrm{ppm} \mathrm{GA}{ }_{3}$ & $210-219$ & $35.6 \pm 1.9^{\mathrm{b}^{* *}}$ & $0.0188 \pm 0.0^{\mathrm{cd} * *}$ & $0.0021 \pm 0.0^{\mathrm{cd}}$ \\
\hline Coated seeds $+500 \mathrm{ppm} \mathrm{GA}$ & $196-209$ & $36.2 \pm 3.1^{\mathrm{b}^{* *}}$ & $0.0183 \pm 0.0^{\mathrm{cd} * *}$ & $0.0053 \pm 0.0^{\mathrm{ab}}$ \\
\hline Coated seeds $+1000 \mathrm{ppm} \mathrm{GA} 3$ & $140-166$ & $62.2 \pm 0.6^{\mathrm{cd} * *}$ & $0.0168 \pm 0.0^{c^{* *}}$ & $0.0004 \pm 0.0^{\mathrm{a}}$ \\
\hline Coated seeds $+2000 \mathrm{ppm} \mathrm{GA} 3$ & $118-126$ & $38.0 \pm 0.9^{\mathrm{b}^{* *}}$ & $0.0185 \pm 0.0^{\mathrm{cd} \mathrm{d}^{* *}}$ & $0.0004 \pm 0.0^{\mathrm{a}}$ \\
\hline Coated seeds $+3000 \mathrm{ppm} \mathrm{GA} 3$ & 98-105 & $55.4 \pm 3.8^{\mathrm{c}^{* *}}$ & $0.0185 \pm 0.0^{\mathrm{cd} * *}$ & $0.0007 \pm 0.0^{\mathrm{a}}$ \\
\hline Coated seeds $+4000 \mathrm{ppm} \mathrm{GA} 3$ & $95-102$ & $69.2 \pm 3.1^{\mathrm{d}^{* *}}$ & $0.0185 \pm 0.0^{\mathrm{cd} * *}$ & $0.0002 \pm 0.0^{\mathrm{a}}$ \\
\hline Coated seeds $+5000 \mathrm{ppm} \mathrm{GA} 3$ & $79-86$ & $63.6 \pm 0.8^{\mathrm{cd} * *}$ & $0.0207 \pm 0.0^{\mathrm{d}^{* *}}$ & $0.0001 \pm 0.0^{\mathrm{a}}$ \\
\hline Decoated seeds $+0 \mathrm{ppm} \mathrm{GA}$ & $15-18$ & $100 \pm 0.0^{\mathrm{e}^{* *}}$ & $0.3150 \pm 0.0^{1 * *}$ & $0.0087 \pm 0.0^{\mathrm{bc} * *}$ \\
\hline Decoated seeds +50 ppm GA 3 & $13-18$ & $100 \pm 0.0^{\mathrm{e}^{* *}}$ & $0.1538 \pm 0.0^{\mathrm{h}^{* *}}$ & $0.0256 \pm 0.0^{\mathrm{fgh}^{* *}}$ \\
\hline Decoated seeds +100 ppm GA 3 & $13-24$ & $100 \pm 0.0^{\mathrm{e}^{* *}}$ & $0.0769 \pm 0.0^{\mathrm{*} *}$ & $0.0104 \pm 0.0^{\mathrm{bc} * *}$ \\
\hline Decoated seeds $+250 \mathrm{ppm} \mathrm{GA}$ & $14-20$ & $100 \pm 0.0^{\mathrm{e}^{* *}}$ & $0.1429 \pm 0.0^{\mathrm{g}^{* *}}$ & $0.0214 \pm 0.0^{\mathrm{efg}^{* *}}$ \\
\hline Decoated seeds $+500 \mathrm{ppm} \mathrm{GA}$ & $11-24$ & $100 \pm 0.0^{\mathrm{e}^{* *}}$ & $0.0485 \pm 0.0^{\mathrm{e}^{* *}}$ & $0.0174 \pm 0.0^{\mathrm{de}^{* *}}$ \\
\hline Decoated seeds $+1000 \mathrm{ppm} \mathrm{GA}_{3}$ & $09-12$ & $100 \pm 0.0^{\mathrm{e}^{* *}}$ & $0.4317 \pm 0.0^{\mathrm{m}^{* *}}$ & $0.0714 \pm 0.0^{\mathrm{j}^{* *}}$ \\
\hline Decoated seeds $+2000 \mathrm{ppm} \mathrm{GA} 3$ & $11-18$ & $100 \pm 0.0^{\mathrm{e}^{* *}}$ & $0.1984 \pm 0.0^{\mathrm{i}^{\mathrm{i} *}}$ & $0.0278 \pm 0.0^{\mathrm{gh}^{* *}}$ \\
\hline Decoated seeds $+3000 \mathrm{ppm} \mathrm{GA}$ & $10-12$ & $100 \pm 0.0^{\mathrm{e}^{* *}}$ & $0.2833 \pm 0.0^{\mathrm{j}^{* *}}$ & $0.0502 \pm 0.0^{\mathrm{i}^{* *}}$ \\
\hline Decoated seeds $+4000 \mathrm{ppm} \mathrm{GA} 3$ & $12-22$ & $100 \pm 0.0^{\mathrm{e}^{* *}}$ & $0.3084 \pm 0.0^{\mathrm{k}^{* *}}$ & $0.0303 \pm 0.0^{h^{* *}}$ \\
\hline Decoated seeds $+5000 \mathrm{ppm} \mathrm{GA}$ & $14-20$ & $100 \pm 0.0^{\mathrm{e}^{* *}}$ & $0.1429 \pm 0.0^{\mathrm{g}^{* *}}$ & $0.0204 \pm 0.0^{\mathrm{e}^{\mathrm{e} * *}}$ \\
\hline
\end{tabular}

The data were statistically assessed by one-way ANOVA, *significant at $P=0.05,{ }^{* *}$ significant at $P=0.01$ level, \pm SE: Standard Error of the mean and means followed by the same letter in the column do not differ significantly by Tukey's post hoc test of Honest Significant Difference.

germination value (0.86) compared to non-treated seeds of only $12.6 \%$ of germination and 0.0009 germination value (Table 2, Fig. $2 d$ ). These experiments revealed that only 4-6 days were taken for initiation to completion of germination compared to coated seed germination without light in a span of $238-254$ days. The $\mathrm{GA}_{3}(1000 \mathrm{ppm})$ pretreatment with decoated seeds in petri dishes without light encouraged seeds contamination and reduced germination percentage compared to decoated seeds germinated in the presence of both light and $\mathrm{GA}_{3}(1000 \mathrm{ppm}$ ) (Fig. 2. b).

The present investigation also gives an idea about optimum seed storage conditions of $G$. imberti. The rate of germination is highly correlated with seed moisture content and storage conditions. During the course of seed storage, the moisture content and germination percentages were negatively correlated and finally the rate of germination became reduced. An interesting observation is that, seed storage was possible both at controlled seed bank conditions $\left(20^{\circ} \mathrm{C} / 20 \% \mathrm{RH}\right)$ and laboratory ambient $\left(28 \pm 2^{\circ} \mathrm{C}, 60 \% \mathrm{RH}\right)$ conditions with above $50 \%$ germination. However, the former method enhanced storage up to 50-60 days but latter showed only 30-40 days of seed storage (Table 3 ). These results clearly indicated that the seed storage was more efficient in seed bank conditions up to 80 days. All the other tested storage condition below $10^{\circ} \mathrm{C}$ found to be futile (Table 3).

Moisture content of seeds negatively affect the storage especially of recalcitrant seeds, which may be overcome through appropriate desiccation levels. Two different moisture contents above the limit of critical moisture contents (CMCs) i.e., 23.3
$\%$ (fast desiccated seed) and $30.5 \%$ (slow desiccated seeds) with $50 \%$ seed germination were selected to test the extension of seed storage in $G$. imberti. These desiccated seeds with reduced moisture content showed higher percentage of germination for long term storage practices compared to storage aspects of fresh seeds with higher moisture content. The 60 days stored fast and slow desiccated seeds in controlled seed bank conditions exhibited 50.4 and $43.4 \%$ of germination respectively compared to fresh, highly moisturized seed storage of $39.4 \%$. Whereas both desiccated 30 days stored seeds registered 84.4 and $78.4 \%$ of germination compared to 76.9 $\%$ of fresh seed storage. The controlled seed bank conditions $\left(20^{\circ} \mathrm{C} / 20 \% \mathrm{RH}\right)$ favoured $G$. imberti seeds for better storage programmes especially fast desiccated seed storage (Table 4).

\section{Discussion}

When considering the seed germination process, awareness about the mechanisms linked to seed dormancy assumes a significant role (16). Nonogaki (17) said that seed dormancy has an ecological relevance, since it maintains the survival mechanism of the seeds, confirming its viability till the ecological conditions are suitable for seedling growth and development. Seed dormancy breaking methods are essential to identify the factors that imposed seed dormancy. The rate and speed of seed germination has been linked with temperature and it affects particularly the rate of water absorption, reactivate metabolic and reserve mobilization processes and seedling growth (1). 
Table 2. Effect of seed decoating, $\mathrm{GA}_{3}$ pre-treatment and light induction (15.4 Lux) (G. imberti seeds; $\left.n=25\right)$.

\begin{tabular}{|c|c|c|c|c|c|c|}
\hline Treatments & $\begin{array}{l}\text { Coated seeds }+ \\
\text { Dark (Control) }\end{array}$ & $\begin{array}{c}\text { Coated } \\
\text { seeds }+ \\
\text { Light }\end{array}$ & $\begin{array}{c}\text { Coated seeds }+ \\
\text { GA }_{3}+\underset{\text { Light }}{\text { Lpm }} \\
\text { ppo0 }\end{array}$ & $\begin{array}{c}\text { Decoated } \\
\text { seeds + Dark }\end{array}$ & $\begin{array}{c}\text { Decoated } \\
\text { seeds + Light }\end{array}$ & $\begin{array}{c}\text { Decoated seeds }+ \\
\text { GA }_{3}+\underset{\text { Light }}{\text { Lpm }}\end{array}$ \\
\hline $\begin{array}{l}\text { Days taken for initiation to } \\
\text { completion of germination }\end{array}$ & $238-254$ & $196-208$ & $136-147$ & $15-19$ & $6-9$ & $4-6$ \\
\hline Germination Percentage & $12.6 \pm 0.4^{\mathrm{a}}$ & $15.8 \pm 1.1^{\mathrm{a}}$ & $24.4 \pm 1.6^{\mathrm{b}^{* *}}$ & $100 \pm 0.0^{\mathrm{c}^{* *}}$ & $100 \pm 0.0^{\mathrm{c}^{* *}}$ & $100 \pm 0.0^{\mathrm{c}^{* *}}$ \\
\hline Speed of Germination & $0.0028 \pm 0.0^{\mathrm{a}}$ & $0.0046 \pm 0.0^{\mathrm{a}}$ & $0.0082 \pm 0.0^{\mathrm{b}^{* *}}$ & $0.3150 \pm 0.0^{\mathrm{c}^{* *}}$ & $0.9607 \pm 0.0^{\mathrm{e}^{* *}}$ & $1.6262 \pm 0.0^{\mathrm{f**}}$ \\
\hline Mean Germination Time & $274 \pm 6.1^{\mathrm{e}}$ & $242 \pm 14.8^{\mathrm{d}^{*}}$ & $208 \pm 3.61^{\mathrm{c}^{* *}}$ & $76.0 \pm 0.89^{b^{* *}}$ & $9.52 \pm 0.02^{\mathrm{a}^{* *}}$ & $5.12 \pm 0.0^{\mathrm{a}^{* *}}$ \\
\hline Mean Daily Germination & $0.0038 \pm 0.0^{\mathrm{a}}$ & $0.0038 \pm 0.0^{\mathrm{a}}$ & $0.0046 \pm 0.0^{\mathrm{a}}$ & $0.2097 \pm 0.0^{\mathrm{b}^{* *}}$ & $0.4706 \pm 0.0^{\mathrm{d}^{* *}}$ & $1.1429 \pm 0.0^{\mathrm{e}^{* *}}$ \\
\hline Peak Value & $0.0030 \pm 0.0^{\mathrm{a}}$ & $0.0031 \pm 0.0^{\mathrm{a}}$ & $0.0041 \pm 0.0^{\mathrm{a}}$ & $0.0418 \pm 0.0^{b^{*}}$ & $0.5200 \pm 0.0^{\mathrm{d}^{* *}}$ & $0.7502 \pm 0.0^{\mathrm{e}^{* *}}$ \\
\hline Germination Value & $0.0009 \pm 0.0^{\mathrm{a}}$ & $0.0010 \pm 0.0^{\mathrm{a}}$ & $0.0020 \pm 0.0^{\mathrm{b}}$ & $0.0087 \pm 0.0^{\mathrm{c}^{* *}}$ & $0.2353 \pm 0.0^{\mathrm{e}^{* *}}$ & $0.8571 \pm 0.0^{\mathrm{f} * *}$ \\
\hline
\end{tabular}

The data were statistically assessed by one-way ANOVA, * significant at $P=0.05,{ }^{* *}$ significant at $P=0.01$ level, \pm SE: Standard Error of the mean and means followed by the same letter in the column do not differ significantly by Tukey's post hoc test of Honest Significant Difference.

Table.3. Effect of seed storage (fresh seeds with $62.8 \% \mathrm{MC} ; n=25)$.

\begin{tabular}{|c|c|c|c|}
\hline Storage conditions & Storage period (Days) & Moisture contents (\%) & Germination (\%) \\
\hline \multirow{9}{*}{$\begin{array}{l}\text { Laboratory ambient condition } \\
\left(28 \pm 2^{\circ} \mathrm{C}, 60 \% \mathrm{RH}\right)\end{array}$} & 0 & $62.8 \pm 4.7^{\mathrm{b}}$ & $100.0 \pm 0.0^{\mathrm{i}}$ \\
\hline & 10 & $66.2 \pm 3.6^{\mathrm{d}^{* *}}$ & $82.4 \pm 5.6^{\mathrm{h}^{* *}}$ \\
\hline & 20 & $66.8 \pm 2.9^{\mathrm{e}^{* *}}$ & $74.5 \pm 6.3^{\mathrm{g}^{* *}}$ \\
\hline & 30 & $67.3 \pm 3.9^{\mathrm{p}^{* *}}$ & $63.5 \pm 5.4^{\mathrm{f**}}$ \\
\hline & 40 & $67.8 \pm 4.1^{\mathrm{g}^{* *}}$ & $39.6 \pm 5.3^{\mathrm{e}^{* *}}$ \\
\hline & 50 & $68.2 \pm 2.4^{\mathrm{h}^{* *}}$ & $33.6 \pm 4.7^{\mathrm{d}^{* *}}$ \\
\hline & 60 & $68.8 \pm 5.1^{\mathrm{i}^{* *}}$ & $26.1 \pm 3.9^{\mathrm{c}^{* *}}$ \\
\hline & 70 & $64.5 \pm 4.7^{\mathrm{c}^{* *}}$ & $13.7 \pm 3.6^{\mathrm{b}^{* *}}$ \\
\hline & 80 & $61.8 \pm 5.6^{\mathrm{a}^{* *}}$ & $0.0 \pm 0.00^{\mathrm{a}^{* *}}$ \\
\hline \multirow{9}{*}{$\begin{array}{l}\text { Controlled condition (Seed bank) } \\
\left(20^{\circ} \mathrm{C} / 20 \% \mathrm{RH}\right)\end{array}$} & 0 & $62.80 \pm 4.7^{\mathrm{a}}$ & $100.0 \pm 0.0^{\mathrm{i}}$ \\
\hline & 10 & $64.8 \pm 3.6^{\mathrm{b}^{* *}}$ & $86.5 \pm 3.6^{\mathrm{h}^{* *}}$ \\
\hline & 20 & $66.5 \pm 3.4^{\mathrm{d}^{* *}}$ & $71.6 \pm 3.5^{\mathrm{f}^{* *}}$ \\
\hline & 30 & $66.9 \pm 4.5^{\mathrm{d}^{* *}}$ & $76.8 \pm 4.6^{\mathrm{g}^{* *}}$ \\
\hline & 40 & $68.3 \pm 2.9^{\mathrm{p}^{* *}}$ & $65.8 \pm 3.2^{\mathrm{e}^{* *}}$ \\
\hline & 50 & $69.5 \pm 3.2^{g^{* *}}$ & $51.4 \pm 3.6^{\mathrm{d}^{* *}}$ \\
\hline & 60 & $67.5 \pm 3.3^{\mathrm{e}^{* *}}$ & $39.4 \pm 4.7^{\mathrm{c}^{* *}}$ \\
\hline & 70 & $65.5 \pm 4.3^{\mathrm{c}^{* *}}$ & $19.6 \pm 3.2^{\mathrm{b}^{* *}}$ \\
\hline & 80 & $65.3 \pm 4.6^{\mathrm{c}^{* *}}$ & $3.3 \pm 0.10^{\mathrm{a} * *}$ \\
\hline \multirow{8}{*}{$10^{\circ} \mathrm{C}$} & 0 & $62.80 \pm 4.7^{\mathrm{a}}$ & $100.0 \pm 0.0^{\mathrm{h}}$ \\
\hline & 10 & $67.8 \pm 5.3^{\mathrm{b}^{* *}}$ & $39.4 \pm 2.3^{\mathrm{g}^{* *}}$ \\
\hline & 20 & $69.5 \pm 6.3^{\mathrm{c}^{* *}}$ & $38.4 \pm 2.6^{\mathrm{f**}}$ \\
\hline & 30 & $70.2 \pm 4.7^{\mathrm{d}^{* *}}$ & $32.5 \pm 2.4^{\mathrm{e}^{* *}}$ \\
\hline & 40 & $70.6 \pm 4.2^{\mathrm{e}^{* *}}$ & $30.2 \pm 3.1^{\mathrm{d}^{* *}}$ \\
\hline & 50 & $74.4 \pm 3.6^{\mathrm{f}^{* *}}$ & $17.5 \pm 1.2^{\mathrm{c}^{* *}}$ \\
\hline & 60 & $73.6 \pm 3.2^{\mathrm{e}^{* *}}$ & $6.8 \pm 0.12^{\mathrm{b}^{* *}}$ \\
\hline & 70 & $72.5 \pm 4.7^{\mathrm{c}^{* *}}$ & $0.0 \pm 0.00^{\mathrm{a}^{* *}}$ \\
\hline \multirow{4}{*}{$0^{\circ} \mathrm{C}$} & 0 & $62.80 \pm 4.7^{\mathrm{a}}$ & $100.0 \pm 0.0^{\mathrm{d}}$ \\
\hline & 10 & $64.3 \pm 1.2^{\mathrm{b}^{* *}}$ & $18.6 \pm 3.8^{\mathrm{c}^{* *}}$ \\
\hline & 20 & $65.3 \pm 3.5^{c^{* *}}$ & $6.3 \pm 2.6^{\mathrm{b}^{* *}}$ \\
\hline & 30 & $66.2 \pm 2.9^{\mathrm{d}^{* *}}$ & $0.0 \pm 0.00^{\mathrm{a}^{* *}}$ \\
\hline \multirow{3}{*}{$-20^{\circ} \mathrm{C}$} & 0 & $62.80 \pm 4.7^{\mathrm{a}}$ & $100.0 \pm 0.0^{c}$ \\
\hline & 10 & $66.3 \pm 3.3^{\mathrm{b}^{* *}}$ & $13.6 \pm 0.13^{b^{* *}}$ \\
\hline & 20 & $66.8 \pm 2.9^{c^{* *}}$ & $0.0 \pm 0.00^{\mathrm{a}^{* *}}$ \\
\hline
\end{tabular}

The data were statistically assessed by one-way ANOVA, ${ }^{*}$ significant at $P=0.05,{ }^{* *}$ significant at $P=0.01$ level, \pm SE: Standard Error of the mean and means followed by the same letter in the column do not differ significantly by Tukey's post hoc test of Honest Significant Difference.

The seeds of $G$. imberti are the only part of propagation that recorded $62.8 \pm 4.7 \%$ initial moisture content. According to Anto and Anilkumar (8) G. imberti seeds exhibited $1.2 \pm$
0.2 years of dormancy with only $38 \pm 1.3 \%$ of germination in in-situ and 6-8 months of dormancy in controlled ex-situ germinator conditions (30 \pm $2^{\circ} \mathrm{C}, 80 \% \mathrm{RH}$, without light). The seed with $0.7-1.2$ 
Table 4. Effect of seed storage (both fast and slow desiccated seeds with 23.31 and $30.53 \%$ MC; $n=25$ ).

\begin{tabular}{|c|c|c|c|}
\hline \multicolumn{2}{|r|}{ Storage condition } & $\begin{array}{c}\text { Storage duration } \\
\text { (days) }\end{array}$ & Germination (\%) \\
\hline \multicolumn{2}{|c|}{ Fresh decoated seeds } & 0 & $100 \pm 00$ \\
\hline \multicolumn{2}{|c|}{ Fast desiccated decoated seeds (MC; 23.31 \%) } & 0 & $54.6 \pm 3.6$ \\
\hline \multicolumn{2}{|c|}{ Slow desiccated decoated seeds (MC; $30.53 \%$ ) } & 0 & $54.4 \pm 4.1$ \\
\hline \multirow{6}{*}{$\begin{array}{l}\text { Laboratory ambient }\left(28 \pm 2^{\circ} \mathrm{C} \text {, }\right. \\
60 \% \mathrm{RH})\end{array}$} & \multirow{2}{*}{ Fresh decoated seeds (MC; $62.8 \%$ ) } & 30 & $63.5 \pm 3.2^{g}$ \\
\hline & & 60 & $26.1 \pm 3.2^{\mathrm{a}}$ \\
\hline & \multirow{2}{*}{ Fast desiccated decoated seeds (MC; $23.31 \%$ ) } & 30 & $72.9 \pm 5.1^{\mathrm{i}}$ \\
\hline & & 60 & $32.8 \pm 2.2^{\mathrm{c}}$ \\
\hline & \multirow{2}{*}{ Slow desiccated decoated seeds (MC; $30.53 \%$ ) } & 30 & $70.5 \pm 3.1^{\mathrm{h}}$ \\
\hline & & 60 & $28.4 \pm 2.6^{\mathrm{b}}$ \\
\hline \multirow{6}{*}{$\begin{array}{l}\text { Controlled (Seed bank) } \\
\text { condition }\left(20^{\circ} \mathrm{C} / 20 \% \mathrm{RH}\right)\end{array}$} & \multirow{2}{*}{ Fresh decoated seeds (MC; $62.8 \%$ ) } & 30 & $76.8 \pm 2.5^{j}$ \\
\hline & & 60 & $39.4 \pm 4.2^{\mathrm{d}}$ \\
\hline & \multirow{2}{*}{ Fast desiccated decoated seeds (MC; $23.31 \%$ ) } & 30 & $84.4 \pm 6.1^{1}$ \\
\hline & & 60 & $50.4 \pm 4.3^{\mathrm{f}}$ \\
\hline & \multirow{2}{*}{ Slow desiccated decoated seeds (MC; $30.53 \%$ ) } & 30 & $78.4 \pm 4.6^{\mathrm{k}}$ \\
\hline & & 60 & $43.4 \pm 2.9^{\mathrm{c}}$ \\
\hline \multirow{3}{*}{ Cryopreservation $\left(-196{ }^{\circ} \mathrm{C}\right)$} & Fresh coated seeds (MC; $62.8 \%$ ) & 7 & - \\
\hline & Fast desiccated decoated seeds (MC; $23.31 \%$ ) & 7 & - \\
\hline & Slow desiccated decoated seeds (MC; $30.53 \%$ ) & 7 & - \\
\hline
\end{tabular}

The data were statistically assessed by one-way ANOVA, ${ }^{*}$ significant at $P=0.05,{ }^{* *}$ significant at $\mathrm{P}=0.01$ level, \pm SE: Standard Error of the mean and means followed by the same letter in the column do not differ significantly by Tukey's post hoc test of Honest Significant Difference.

mm thick hard coat enforces deep dormancy. Baskin and Baskin (18) reported that seed dormancy is usually allied with intrinsic factors linked to the seed itself, such as rigid and impermeability of the seed coat to gases and water, immature embryos, inhibitors, and abiotic factors like temperature, humidity, light and substrate. The G. imberti seeds when subjected to decoating, dormancy were also reduced (8). The seed decoating was efficient for avoiding the inhibitory phyto-compounds present (19). These results revealed that the $G$. imberti seeds possess mainly physical dormancy along with mild physiological dormancy. Dormancy breaking methods tried with $G$. kola seeds reported by EyogMatig et al. (20) suggested that seed coat removal followed by dipping in cold water $\left(25^{\circ} \mathrm{C}\right)$ reduces the dormancy. Total removal of $G$. cowa seed coat was considered as the most efficient dormancybreaking methods (21) and (22).

The present study showed that, decoated G. imberti seeds with $\mathrm{GA}_{3}$ displayed significant enhancement of germination and associated parameters. The higher concentration of $\mathrm{GA}_{3}$ (1000-4000 ppm) applied on seeds showed cent percentage germination and improved germination values. The $\mathrm{GA}_{3}$ treatment is used for releasing inhibitory phyto-compounds present in seeds (23). Kouakou et al. (19) reported that scarification along with $\mathrm{GA}_{3}$ application on $G$. kola seeds offer an alternative procedure to progress the seed germination and seedling vigour for a large-scale seedling production for species conservation.
The G. imberti decoated seeds applied with $\mathrm{GA}_{3}$ of $1000 \mathrm{ppm}$ showed cent percent germination with germination value of $0.07 \pm 0.00$ against $0.009 \pm 0.00$ of non-treated decoated seeds. A similar case of best percentage of germination was reported with $G$. kola scarified seeds treated with $\mathrm{GA}_{3}$ of $10^{-2}$ to $10^{-4} \mathrm{~g} \mathrm{~L}^{-1}$ for 24 to 48 hours respectively (19). Germination rates of G. kola seeds were $0.012 \pm 0.00$ and $0.013 \pm 0.00$ for $10^{-4}$ and $10^{-3} \mathrm{~g} \mathrm{~L}^{-1}$ of $\mathrm{GA}_{3}$, respectively, compared to scarified seeds untreated with $\mathrm{GA}_{3}$ as control of $0.010 \pm 0.00$ (19). These treatment combination (Decoated seeds $+\mathrm{GA}_{3} 1000 \mathrm{ppm}$ ) taken only 09-12 days for its complete germination compared to non-treated coated G. imberti seeds of 238-254 days.

The results of different dormancy breaking methods in $G$. imberti indicate that light along with $\mathrm{GA}_{3}$ are the major factors to release the physiological dormancy and enhance germination. Especially decoated seeds contacted with light (15.4 Lux) and $\mathrm{GA}_{3}(1000 \mathrm{ppm})$ showed a promising value of cent percent germination and superior germination value. These experiments revealed that only 4-6 days taken for the completion of seed germination in the presence of light compared to 238-254 days for the coated seeds without light. The $\mathrm{GA}_{3}$ applied decoated seeds in petri dishes without light exhibited seeds contamination and reduced rate of germination. These experiments clearly indicated the influence of both light and decoating for initiation of germination. The light intensity, which greatly influences the seed germination is responsible for the perception and translation of the shining stimulus (17). Seed 
dormancy is overcome by exogenous application of $\mathrm{GA}_{3}$ and light in Rheumemodi seeds reported by Kandari et al. (24). Several cultivated species are uninterested to light to sprout; but, the light is very essential and it stimulates seeds of various wild species (25). Alternating temperature treatments with light dramatically improved the germination process of Cuphea viscosissima dormant seeds reported by Widrlechner and Kovach (26).

The present study also gives a clue about optimum seed storage conditions of G. imberti. Storage environment is very important for extending seed's life and the ideal metabolic rate in storage will conserve as much of the stored food reserves in the seeds and maintains the integrity of the embryos (27). King and Roberts (28) clarified storage life span of hydrated (recalcitrant) seeds from days or weeks for some tropical species and reported that rate of seed germination is highly associated with seed moisture content and storage conditions. Seed morphology, chemical composition, maturity, storage environments which includes temperature, moisture, storage facilities of cold storage, containers and moisture regulators plays an important role on successful seed storage $(29,30)$. An interesting observation is that, G. imberti seeds stored at controlled (Seed bank $20^{\circ} \mathrm{C} / 20 \% \mathrm{RH}$ ) conditions registered nearly $50 \%$ germination up to 50-60 against 30-40 days at laboratory ambient $\left(28 \pm 2{ }^{\circ} \mathrm{C}, 60 \% \mathrm{RH}\right)$ conditions. The general objective of seed storage is to lessen the metabolism of the seeds as much as possible without harm them and to avoid attack by microorganisms (29). The results clearly indicated that the $G$. imberti seed storage was more effective in seed bank conditions up to 80 days.

Extreme cold storage was not efficient for G. imberti seed conservation since low temperatures like $0^{\circ} \mathrm{C}$ and $-20^{\circ} \mathrm{C}$ exhibited very less rate of germination in 10 days. At this chilling temperature, seeds respire and produce moisture content which could not be used for the on-going metabolism which eventually recedes and henceforth the initially formed respired moisture content become condensed in the hermitic storage. Seed storage temperature below $15^{\circ} \mathrm{C}$ has been reported to be dangerous for most tropical recalcitrant seeds $(29,31)$. Chitra (32) reported that fresh desiccated seeds of Coscinium fenestratum stored with $6.8 \% \mathrm{MC}$ at 30 and $20^{\circ} \mathrm{C}$ retained $80 \%$ viability. This loss of viability is generally due to the physical, chemical and metabolic changes which can destruct both the cell membrane and cytoplasm (1). Bonner (29) reported that tropicalrecalcitrant seeds like Quercus acorns seeds registered higher lethality in low temperature and chilling damage below 12 to $20^{\circ} \mathrm{C}$. Yong et al. (22) reported that $G$. cowa seed viability was depleted rapidly when seeds were stored at $4^{\circ} \mathrm{C}$, which registered only $2 \%$ germination after 1 week.
Similarly, G. subelliptica seeds in $<4^{\circ} \mathrm{C}$ storage temperature were also registered very fewer viability loss when the moisture became $30 \%$ (33).

Seed moisture content negatively affect the stored seeds especially recalcitrant seeds, though proper desiccation overcome this difficulty linked with viability retention. During the study, a clear difference was observed in germination rate between fresh and stored seeds. Previous results on both fast and slow seed desiccation with two different moisture contents (MCs) viz. 23.3 and $30.5 \%$ respectively registered 50.5 and $43.0 \%$ germination (7). The present study was with these two MCs, (without exceeding the critical moisture contents) standardized G. imberti seed storage practices. It was also revealed that the CMCs may also vary with the method of desiccation (34).

The seed storage behaviour of $G$. imberti is determined after drying the seeds to two different moisture levels (fast and slow desiccated seeds) and assessing the corresponding rate of germination. The 60 days stored fast and slow desiccated seeds in controlled seed bank conditions exhibited 50.4 and $43.4 \%$ of germination compared to fresh highly moisturized seed stored with $39.4 \%$ germination. Whereas both desiccated 30 days stored seeds with 23.3 and $30.5 \%$ MC registered 84.4 and $78.4 \%$ of germination compared to $76.8 \%$ of fresh seed storage. The fast desiccation was more effective than slow desiccation for G. imberti seeds (8) and fast desiccated seeds stored in controlled seed bank conditions $\left(20^{\circ} \mathrm{C} / 20 \% \mathrm{RH}\right)$ favoured better storage programmes. The fast desiccated seeds exposed to intermediary levels of hydration only for a short-term period which in turn shortened the possible damage linked with desiccation (33). Goncalves et al. $(35,36)$ point out that, fast dried seeds of Citrus reshni were more beneficial and it provided more root projection along with lesser percentage of anomalous seedlings. The knowledge on optimal seed germination and seed storage conditions are vital factors for any effort towards the maintenance of a plant species (37). Drew et al. (38) reported that recalcitrant seeds with reduced quality weaken the storage life span, which was confirmed with the storage behaviour of Trichilia dregeana and Inga vera. Seeds of $T$. dregeana with poor quality dropped viability from 100 to $20 \%$ when stored wet over three weeks at $16^{\circ} \mathrm{C}$. The desiccated, cryo stored $G$. imberti seeds were also futile due to its recalcitrant nature. Pammenter and Berjak (39) pointed out that the main possible problem in cryopreservation of seeds is the formation of intracellular ice crystals that can be fatal to the tissue.

\section{Conclusion}

Seed decoating and $\mathrm{GA}_{3}$ pre-treatments along with exposure to light are the most suitable methods to eliminate complete physical and physiological 
dormancy of G. imberti seeds. Seed storage was more efficient in seed bank conditions though for a limited period up to 80 days due to recalcitrant nature. The desiccated seeds especially fast desiccated seeds in $20^{\circ} \mathrm{C} / 20 \% \mathrm{RH}$ registered maximum life span compared to other storage practices.

\section{Acknowledgements}

We wish to thank the Director, Jawaharlal Nehru Tropical Botanic Garden and Research Institute for the facilities provided and Kerala Forest Department for forest entry permit. The first author also thanks the University of Kerala for the approved Ph.D. programme on Garcinia imberti.

\section{Conflict of interest}

The authors declared that they have no conflict of interest.

\section{Authors' Contribution}

$\mathrm{AM}$ and AM collected the seed samples from the field, carried out the work, analysed the data. JPS and AC interpreted the data and helped in manuscript writing.

\section{References}

1. Bewley JD, Black M. Seeds: Physiology of development and germination. $2^{\text {nd }}$ ed. Plenum Press, New York. P:445. 1994. https://doi.org/10.1007/978-1-4899-1002-8 9

2. Arora R, Bhojwani SS. In vitro propagation and low temperature storage of Saussurea lappa C. B. Clarke - an endangered medicinal plant. Plant Cell Report 1989; 8: 4447. https://doi.org/10.1007/BF00735776

3. Deno, N. Seed Germination Theory and Practice. $2^{\text {nd }}$ ed. (self-published) State College, PA 1993.

4. Taiz L, Zeiger E. Plant Physiology, Chapter 23. Abscisic Acid: A Seed Maturation and Antistress Signal, $3^{\text {rd }}$ ed. Sinauer Associates, Inc., Sunderland, MA, 2002; pp. 538558.

5. Soyler D, Khawar KM. Seed germination of Caper (Capparis ovata var. herbacea) using a naphthalene acetic acid and gibberillic acid. International Journal of Agriculture and Biology 2007; 9(1):35-37.

6. Pons TL. Seed responses to light. In Fenner M (ed). Seeds: The Ecology of Regeneration in Plant Communities. $2^{\text {nd }}$ ed. Wallingford, UK:CABI Publishing. 2000; 237-260. https://doi.org/10.1079/9780851994321.0237

7. World Conservation Monitoring Centre. Garcinia imberti. The IUCN Red List of Threatened Species; 1998. http://dx.doi.org/10.2305/IUCN.UK.1998.RLTS.T31166A960 4991.en Downloaded on 01 March 2019.

8. Anto M, Anilkumar C. Impact of fast and slow desiccation on Garcinia imberti seed and seedling vigour. Plant Science Today 2018; 5(3):95-105 https://dx.doi.org/10.14719/pst.2018.5.3.398

9. Anilkumar C, Prajith TM, Jothish PS, Ashraf A. Seed germination behaviour of Garcinia imberti Bourd. Indian Forester 2016;142:196-899.
10. Ekta K, Singh JS. Ecology of tree seed and seedlings: implications for tropical forest conservation and restoration. Current Science 2001;80:748-757.

11. Hong TD, Linington S, Ellis RH. Seed Storage Behaviour: A Compendium. Handbooks for Genebanks, No. 4. International Plant Genetic Resources Institute, Rome. 1996.

12. Linington, SH, Pritchard HW. Gene Banks. In Levin SA. (ed) Encyclopedia of biodiversity (3). San Diego, Academic Press. 2001;165-181. https://doi.org/10.1016/B0-12-226865$\underline{2 / 00135-8}$

13. Umarani R, Aadhavan EK, Faisal MM. Understanding poor storage potential of recalcitrant seeds. Current Science 2015;108 (11):2023-2034.

14. Ellis RH, Roberts EH. The quantification of ageing and survival in orthodox seeds. Seed Science and Technology 1981;9:373-409.

15. Czabator FJ. Germination value: an index combining speed and completeness of pine seed germination. Forest Science 1962;8:386- 395.

16. Bradbeer JW. Seed dormancy and germination. Springer Science and Business Media 2013; p:146.

17. Nonogaki H. Seed dormancy and germination emerging mechanisms and new hypotheses. Frontiers in plant science 2014;5:1-14. https://doi.org/10.3389/fpls.2014.00233

18. Baskin CC, Baskin JM. Seeds. Ecology, biogeography and evolution of dormancy and germination. San Diego: Academic Press. 1998. pp 666.

19. Kouakou KL, Kouakou, C, Koffi KK, Dao J, Beugre MM, Baudoin J, Zoro Bi IA. Effect of mechanical scarification and gibberellins $\left(\mathrm{GA}_{3}\right)$ on seed germination and growth of Garcinia kola (Heckel). Journal of Applied Biosciences 2016;103:9811-9818.

20. Eyog-matig O, Aoudji AKN, Linsoussi C. Garcinia kola Heckel seeds dormancy-breaking. Applied Ecology and Environmental Research 2007;5(1):63-71. https://doi.org/10.15666/aeer/0501 063071

21. Liu Y, qiu Y, Zhang L, Chen J. Dormancy Breaking and Storage Behavior of Garcinia cowa Roxb. (Guttiferae) Seeds: Implications for Ecological Function and Germplasm Conservation. Journal of Integrative Plant Biology 2005;47(1):38-49. https://doi.org/10.1111/j.17447909.2005.00010.x

22. Yong LIU, Yu-Ping QIU, Ling ZHANG, Jin CHEN. Dormancy breaking and storage behavior of Garcinia cowa (Guttiferae) Seeds: implications for ecological function and germplasm conservation. Journal of Integrative Plant Biology 2005;47(1):38-49. https://doi.org/10.1111/j.17447909.2005.00010.x

23. Kouakou LK, Zoro Bi IA, Yao KA, Tanoh HK, Baudoin JP. Rapid seedlings regeneration from seeds and vegetative propagation with sucker and rhizome of Eremospatha macrocarpa (Mann \& Wendl.) Wendl and Laccosperma secundiflorum (P. Beauv.) Kuntze. Scientia Horticulturae 2009;120:257-263. https://doi.org/10.1016/j.scienta.2008.10.011

24. Kandari LS, Rao KS, Payal KC, Maikhuri RK, Chandra A, Vanstaden JV. Conservation of aromatic medicinal plant Rheum emodi Wall ex Messi. through improved seed germination. Seed Science and Technology 2012;40:95101. https://doi.org/10.15258/sst.2012.40.1.10

25. Miranda RMD, Dias DCFDS, Picoli EAD, Silva PPD, Nascimento WM. Physiological quality, anatomy and histochemistry during the development of carrot seeds (Daucus carota L.). Ciência e Agrotecnologia 2017;41:169180. https://doi.org/10.1590/1413-70542017412009216 
26. Widrlechner MP, Kovach D A. Dormancy-breaking protocols for Cuphea seed. Seed Science and Technology 2000;28:1-27.

27. Patil SS, Krishna A. Influence of seed moisture content on seed germination and quality in canes. Journal of Plant Science and Research 2016;3(2):156.

28. King MW, Roberts EH. Maintenance of recalcitrant seeds in storage. Pp. 53-89 in Recalcitrant Crop Seeds. (HF. Chin and EH. Roberts, eds.). Tropical Press, Kuala Lumpur. 1980.

29. Bonner FT. Storage of Seeds. Woody Plant Seed Manual. 2008. pp 85-96.

30. Govender M, Dye, PJ, Weiersbye IM, Witkowski ETF, Ahmed F. Review of commonly used remote sensing and ground-based technologies to measure plant water stress. Water SA. 2009;35(5):741-752. https://doi.org/10.4314/wsa.v35i5.49201

31. Bedi S, Basra AS. Chilling injury in germinating seeds: Basic mechanisms and agricultural implications. Seed Science Research https://doi.org/10.1017/S0960258500001847

32. Chitra CR. Seed Biology of Coscinium fenestratum (Gaertn.) Colebr. Thesis submitted to the University of Kerala. 2018 (unpublished).

33. Yang J, Kuo S, Lee C. Germination and Storage Behavior of seeds of Garcinia subelliptica (Guttiferae), Drypetes littoralis (Euphorbiaceae), and Premna serratifolia (Verbenaceae). Taiwan Journal of Forest Science 2010;25 (4):339-352.
34. Pritchard HW. Water potential and embryonic axis viability in recalcitrant seeds of Quercus rubra. Annals of Botany 1991;67:43-49. https://doi.org/10.1093/oxfordjournals.aob.a088098

35. Wesley - Smith J, Pammenter NW, Berjak P, Walters C. The effects of two drying rates on the desiccation tolerance of embryonic axes of recalcitrant jack fruit (Artocarpus heterophyllus Lamk.) seeds. Annals of Botany 2001;88:653664. https://doi.org/10.1006/anbo.2001.1519

36. Goncalves MLF, Faria JMR, Jose AC, Tonetti OAO, Marques ER. Desiccation tolerance and antioxidant enzymatic activity in Citrus reshni seeds exposed to various drying rates. Seed Science and Technology 2017;45:411-427. https://doi.org/10.15258/sst.2017.45.2.08

37. Daskalakou EN, Thanos CA, Georghiou K. Seed biology, reproductive phenology and conservation of Cedrus brevifolia, a threatened endemic tree of Cyprus. Seed Science and Technology 2015;43(3):378-389. https://doi.org/10.15258/sst.2015.43.3.05

38. Drew PJ, Pammenter NW, Berjak P. 'Sub-imbibed' storage is not an option for extending longevity of recalcitrant seeds of the tropical species, Trichilia dregeana Sond. Seed Science Research 2000;10:355-363. https://doi.org/10.1017/ $\underline{\text { S0960258500000398 }}$

39. Pammenter NW, Berjak P. Physiology of desiccationsensitive (recalcitrant) seeds and the implications for cryopreservation. International Journal of Plant Sciences 2014;175(1):21-28. https://doi.org/10.1086/673302 